\title{
INFLUENCE OF COMPOSITION AND MICROSTRUCTURE ON THE FEATURES OF MECHANICAL PROPERTIES OF Co-Cr-Fe-Mn-Ni HIGH ENTROPY ALLOYS
}

\author{
A.V. Levenets ${ }^{1}$, I.V. Kolodiy ${ }^{2}$, N.V. Berezhnaya ${ }^{2}$, Y.S. Lipovskaya ${ }^{2}$ \\ ${ }^{I}$ Department of Physics and Technology, V.N. Karazin Kharkiv National University \\ Svobody Sq.4, 61022 Kharkiv, Ukraine \\ ${ }^{2}$ NSC «Kharkiv Institute of Physics and Technology», \\ Academicheskaya Str.1, 61108 Kharkiv, Ukraine \\ e-mail:avlevenets@gmail.com \\ Received February 20, 2017
}

The structure and mechanical properties of high-entropy CoCrFeMnNi (equiatomic) and $\mathrm{Co}_{20} \mathrm{Cr}_{26} \mathrm{Fe}_{20} \mathrm{Mn}_{20} \mathrm{Ni}_{14}$ alloys, which differ significantly in the stacking-fault energy, are studied. The structure of the alloys was investigated in three states - as-cast, after homogenizing annealing at $\mathrm{T}=1000{ }^{\circ} \mathrm{C}$ for $24 \mathrm{~h}$ and after annealing at $\mathrm{T}=850{ }^{\circ} \mathrm{C}$. It was found that in the cast state and after homogenizing annealing at $1000{ }^{\circ} \mathrm{C}$ both alloys are single-phase solid solutions with a FCC lattice. Annealing at $850{ }^{\circ} \mathrm{C}$ preserves the single-phase state in the equiatomic $\mathrm{CoCrFeMnNi}$ alloy, but leads to the appearance of a $\sigma$-phase in the $\mathrm{Co}_{20} \mathrm{Cr}_{26} \mathrm{Fe}_{20} \mathrm{Mn}_{20} \mathrm{Ni}_{14}$ alloy. The mechanical properties of these alloys were studied in a single-phase state by uniaxial compression tests and hardness measurements. It was discovered, that both alloys in a single-phase state had high plasticity and tendency to force strain hardening. The behavior of hardening coefficients in the area of true strains $\mathrm{e}=0.05-0.17$ vary considerably. This may be due to a significant difference in the stacking-fault energy of the investigated alloys. As a result, in $\mathrm{Co}_{20} \mathrm{Cr}_{26} \mathrm{Fe}_{20} \mathrm{Mn}_{20} \mathrm{Ni}_{14}$ alloy along with dislocation deformation mechanism there is a high probability of implementation the twinning mechanism.

KEYWORDS: high-entropy alloys, Co-Cr-Fe-Mn-Ni alloys, stacking-fault energy, mechanical properties, deformation mechanism

\section{ВЛИЯНИЕ СОСТАВА И МИКРОСТРУКТУРЫ НА ОСОБЕННОСТИ МЕХАНИЧЕСКИХ СВОЙСТВ ВЫСОКОЭНТРОПИЙНЫХ СПЛАВОВ СИСТЕМЫ Co-Cr-Fe-Mn-Ni}

А.В. Левенец ${ }^{1}$, И.В. Колодий ${ }^{2}$, Н.В.Бережная ${ }^{2}$, Ю.С. Липовская ${ }^{2}$

${ }^{l}$ Физико-технический факультет, Харьковский национальный университет имени В.Н. Каразина пл. Свободыл 4, 61022 Харьков, Украина

${ }^{2}$ ННЦ "Харьковский физико-технический институт"

ул. Академическая 1, 61108 Харьков. Украина

Исследованы структура и механические свойства высокоэнтропийных сплавов $\mathrm{CoCrFeMnNi}$ (эквиатомный) и $\mathrm{Co}_{20} \mathrm{Cr}_{26} \mathrm{Fe}_{20} \mathrm{Mn}_{20} \mathrm{Ni}_{14}$, которые значительно отличаются энергией дефектов упаковки. Структура сплавов исследовалась в трех состояниях - после отливки, после гомогенизирующего отжига при $\mathrm{T}=1000{ }^{\circ} \mathrm{C}$ в течении 24 часов и после отжига при $\mathrm{T}=850^{\circ} \mathrm{C}$. Было обнаружено, что в литом состоянии и после гомогенизирующего отжига при $1000^{\circ} \mathrm{C}$ оба сплава являются однофазными твердыми растворами с ГЦК-решеткой. Отжиг при $850{ }^{\circ} \mathrm{C}$ сохраняет однофазное состояние в эквиатомном сплаве $\mathrm{CoCrFeMnNi}$, но приводит к появлению б-фазы в сплаве $\mathrm{Co}_{20} \mathrm{Cr}_{26} \mathrm{Fe}_{20} \mathrm{Mn}_{20} \mathrm{Ni}_{14}$. Механические свойства этих сплавов изучались в однофазном состоянии с помощью испытаний на одноосное сжатие и измерение твердости. Было обнаружено, что оба сплава в однофазном состоянии обладают высокой пластичностью и склонностью к сильному деформационному упрочнению. При этом поведение коэффициентов упрочнения в области истинных деформаций е $=0,05-0,17$ существенно различается. Это может быть обусловлено значительным различием энергии дефектов упаковки в исследуемых сплавах, в результате чего в сплаве $\mathrm{Co}_{20} \mathrm{Cr}_{26} \mathrm{Fe}_{20} \mathrm{Mn}_{20} \mathrm{Ni}_{14}$ наряду с дислокационным механизмом деформации велика вероятность реализации механизма двойникования.

КЛЮЧЕВЫЕ СЛОВА: высокоэнтропийные сплавы, сплавы Co-Cr-Fe-Mn-Ni, энергия дефектов упаковки, механические свойства, деформационный механизм

\section{ВПЛИВ СКЛАДУ І МІКРОСТРУКТУРИ НА ОСОБЛИВСТІ МЕХАНІЧНИХ ВЛАСТИВОСТЕЙ ВИСОКОЕНТРОПІЙНИХ СПЛАВІВ СИСТЕМИ Сo-Cr-Fe-Mn-Ni \\ А.В. Левенець ${ }^{1}$, І.В. Колодій ${ }^{2}$, Н.В. Бережная ${ }^{2}$, Ю.С. Липовська ${ }^{2}$ \\ ${ }^{l}$ Фізико-технічний факультет, Харківський національний університет імені В.Н. Каразіна м. Свободи 4, 61022 Харків, Украӥна \\ ${ }^{2}$ ННЦ "Харківський фізико-технічний інститут" вул. Академічна 1, 61108 Харків, Україна}

Досліджено структуру та механічні властивості високоентропійних сплавів $\mathrm{CoCrFeMnNi} \mathrm{(еквіатомний)} \mathrm{i}$ $\mathrm{Co}_{20} \mathrm{Cr}_{26} \mathrm{Fe}_{20} \mathrm{Mn}_{20} \mathrm{Ni}_{14}$, які значно відрізняються енергією дефектів упаковки. Структура сплавів досліджувалась в трьох станах - після виливки, після гомогенізуючого відпалу при $\mathrm{T}=1000{ }^{\circ} \mathrm{C}$ протягом 24 годин і після відпалу при $\mathrm{T}=850{ }^{\circ} \mathrm{C}$. Було виявлено, що в литому стані і після гомогенізуючого відпалу при $1000{ }^{\circ} \mathrm{C}$ обидва сплави є однофазними твердими розчинами з ГЦК-решіткою. Відпал при $850{ }^{\circ} \mathrm{C}$ зберігає однофазний стан в еквіатомному сплаві $\mathrm{CoCrFeMnNi,} \mathrm{aле}$ призводить до появи б-фази в сплаві $\mathrm{Co}_{20} \mathrm{Cr}_{26} \mathrm{Fe}_{20} \mathrm{Mn}_{20} \mathrm{Ni}_{14}$. Механічні властивості сплавів вивчалася в однофазному стані за допомогою випробувань на одновісне стиснення і вимір твердості. Було встановлено, що обидва сплави в однофазному стані мають високу пластичність і схильність до сильного деформаційного зміцнення. При цьому поведінка коефіцієнтів зміцнення в області дійсних деформацій е $=0,05-0,17$ істотно розрізняється. Це може бути обумовлено значною різницею (C) Levenets A.V., Kolodiy I.V., Berezhnaya N.V., Lipovskaya Y.S., 2017 
енергії дефектів пакування в досліджуваних сплавах, в результаті чого, в сплаві $\mathrm{Co}_{20} \mathrm{Cr}_{26} \mathrm{Fe}_{20} \mathrm{Mn}_{20} \mathrm{Ni}_{14} \quad$ поряд iз дислокаційним механізмом деформації велика ймовірність реалізації механізму двійникування.

КЛЮЧОВІ СЛОВА: високоентропійні сплави, сплави Co-Cr-Fe-Mn-Ni, енергія дефектів упаковки, механічні властивості, механізм деформації

High-entropy (or concentrated multicomponent) alloys, actively studied in recent years, are of interest not only for various technical applications [1,2], but also in terms of establishing the features of their structure formation and mechanisms of various physical processes, in particular the plastic deformation processes. A typical representative of high-entropy alloys (HEA's) is an equiatomic CoCrFeMnNi alloy (Cantor alloy), which is a solid solution with a FCC lattice $[3,4]$. There are a number of works in which the mechanical properties of this alloy are studied, but opinions on plastic deformation mechanisms vary greatly. For example, in [5] after the rolling deformation at room temperature the presence of twins was detected at a deformation degree of more than $20 \%$, whereas in [6] after the tension deformation twins have been observed only at the largest deformations (near destruction). It is known that both the kind of loading and certain "internal" features of alloy (in particular, the stacking-fault energy) significantly influence on the deformation mechanism.

The aim of this work was to study the microstructure and mechanical properties of equiatomic $\mathrm{CoCrFeMnNi}$ and non-equiatomic $\mathrm{Co}_{20} \mathrm{Cr}_{26} \mathrm{Fe}_{20} \mathrm{Mn}_{20} \mathrm{Ni}_{14}$ (in at \%) alloys after the compression deformation. They have different stackingfault energy (19 and $3.5 \mathrm{mJm}^{-2}$, accordingly [7]).

\section{MATERIALS AND METHODS}

CoCrFeMnNi and $\mathrm{Co}_{20} \mathrm{Cr}_{26} \mathrm{Fe}_{20} \mathrm{Mn}_{20} \mathrm{Ni}_{14}$ alloys were melted in arc furnace in argon atmosphere. The purity of initial metals wasn't less than $99.9 \%$. To ensure composition and microstructure uniformity ingots were remelted 5 times, turning them every melting. Before the investigations samples were annealed at $1000{ }^{\circ} \mathrm{C} 24 \mathrm{~h}$, some of the samples were also annealed at $\mathrm{T}=850^{\circ} \mathrm{C}$.

Samples preparation for microstructural studies was carried out by grinding on waterproof abrasive paper with grit from 300 to 1000 with subsequent polishing with diamond paste on the velvet. Final polishing was performed on pure velvet with gasoline. For microstructure detection samples were etched in the following reagent: $\mathrm{HNO}_{3}-1$ part, $\mathrm{HF}-1$ part, $\mathrm{H}_{2} \mathrm{O}-1$ part, $\mathrm{H}_{2} \mathrm{SO}_{4}-$ few drops. Etching time was $15 \div 20$ seconds.

$\mathrm{X}$-ray diffraction analysis was carried out using DRON-4-07 diffractometer in a copper $\mathrm{Cu}-\mathrm{K} \alpha$ radiation. Mechanical properties were studied under uniaxial compression conditions at room temperature. Samples for mechanical tests were prepared by spark cutting in a parallelepiped form size of $4 \times 4 \times 3.8 \mathrm{~mm}^{3}$, and following faces grinding on a special device with the abrasive grit paper with grit from 400 to 2000. Compression test was conducted on a universal testing machine $1958 \mathrm{y}-10$ at a strain rate of $0.17 \mathrm{~mm} / \mathrm{min}$. After loading up to a certain value the samples were unloaded, their geometric parameters were measured and on planes, perpendicular to the compression axis, the Vickers hardness was measured on a universal instrument $2137 \mathrm{TY}$ with a load of $20 \mathrm{~kg}$. Then samples were subjected to compression deformation again and yield strength and hardness were measured. This procedure was carried out several times; the dependence of hardness and yield strength on the pre-compression deformation value was built from obtained results.

\section{RESULTS AND DISCUSSION \\ The microstructure}

As-cast alloys have a typical dendritic microstructure (Fig. 1a). At the same time, as shown previously [1], dendrites (marked as number 1) enriched with $\mathrm{Co}, \mathrm{Cr}$ and $\mathrm{Ni}$ and the interdendritic space (marked as number 2) with $\mathrm{Ni}$ and $\mathrm{Mn}$. After homogenizing annealing at $1000{ }^{\circ} \mathrm{C}$, the alloys have a grain microstructure with a grain size of several hundred micrometers (Fig. 1b).

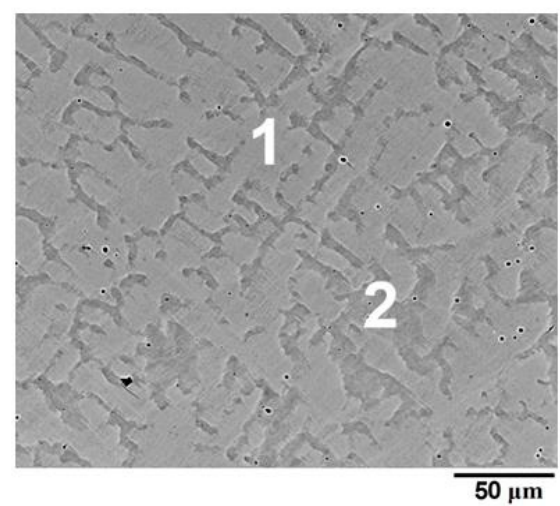

a

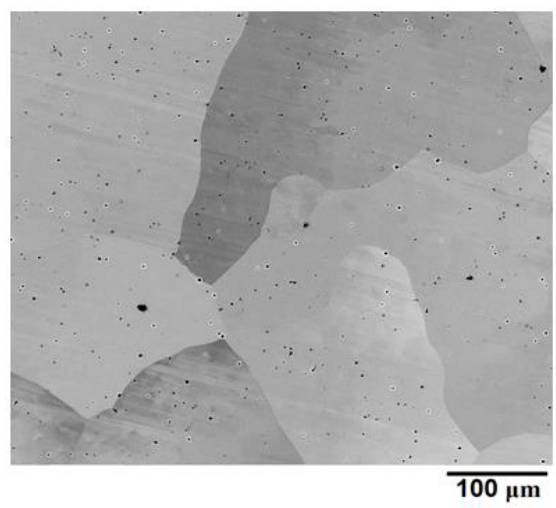

6

Fig. 1. Microstructure of the samples after melting (a) and annealing at $1000^{\circ} \mathrm{C}$ for 24 hours (b). 


\section{The crystal structure}

$\mathrm{X}$-ray studies have shown that the equiatomic CoCrFeMnNi alloy in as-cast state and after homogenizing annealing is a single-phase solid solution with a FCC lattice $(\mathrm{a}=3.602 \AA)$, which is in full accordance with the known literature data [2]. $\mathrm{Co}_{20} \mathrm{Cr}_{26} \mathrm{Fe}_{20} \mathrm{Mn}_{20} \mathrm{Ni}_{14}$ alloy in the cast state is also a single-phase FCC solid solution. The structural state of the $\mathrm{Co}_{20} \mathrm{Cr}_{26} \mathrm{Fe}_{20} \mathrm{Mn}_{20} \mathrm{Ni}_{14}$ alloy depends on the annealing temperature.

Annealing at $1000^{\circ} \mathrm{C}$ preserves the single-phase state of the alloy, the FCC lattice parameter is $3.583 \pm 1 \cdot 10^{-3} \AA$. After annealing at $850{ }^{\circ} \mathrm{C}$ the alloy is two-phase - along with the main FCC-phase the $\sigma$-phase is present in the alloy (Fig. 2). In this case, the lattice parameter of the FCC-phase is $\mathrm{a}=3.603 \pm 1 \cdot 10^{-3} \AA$ and the lattice parameters of the $\sigma$ phase are $\mathrm{a}=8,797 \AA, \mathrm{c}=4,557 \AA$.

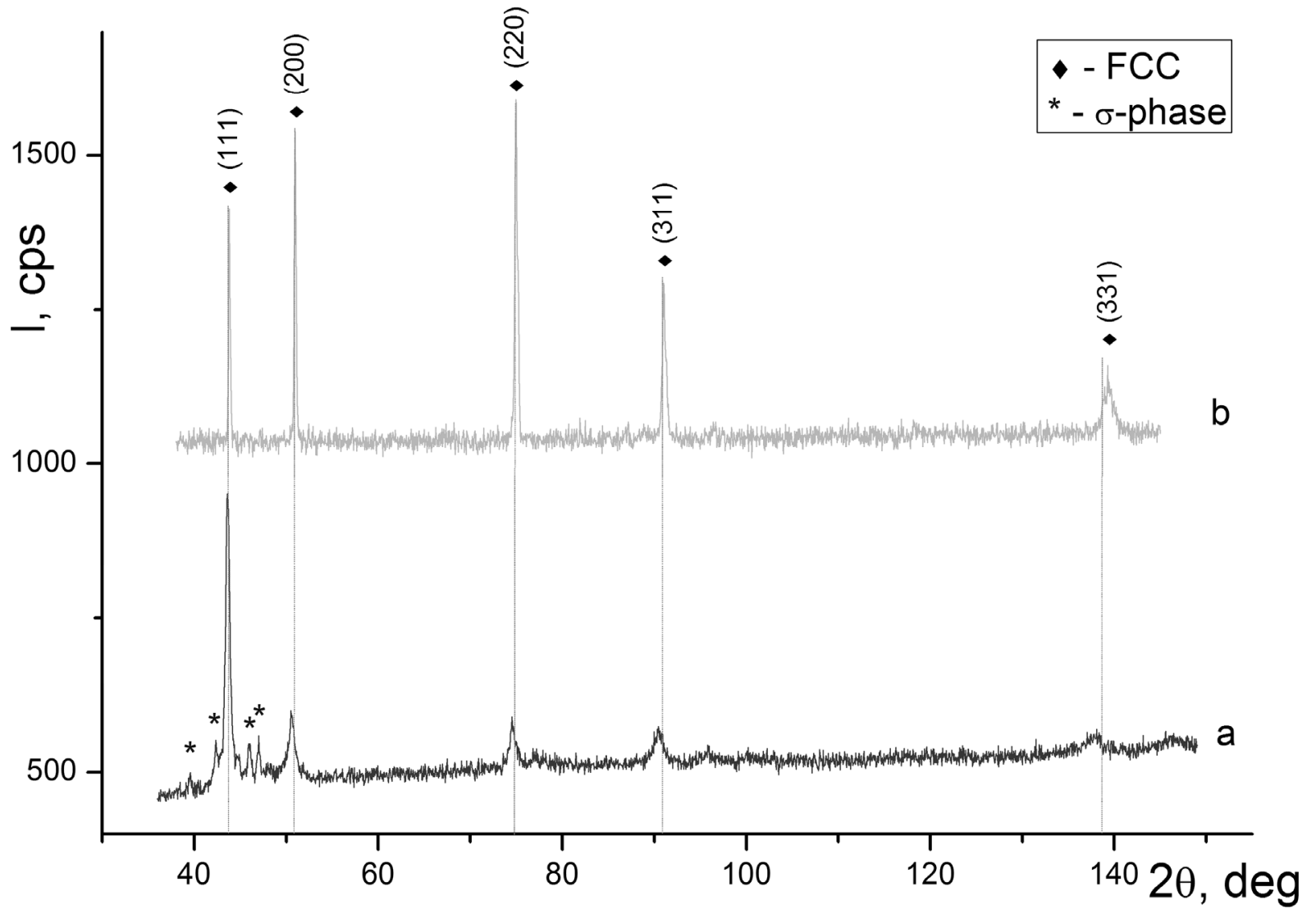

Fig. 2. Diffraction patterns of $\mathrm{Co}_{20} \mathrm{Cr}_{26} \mathrm{Fe}_{20} \mathrm{Mn}_{20} \mathrm{Ni}_{14}$ alloy a - after annealing at $\mathrm{T}=850^{\circ} \mathrm{C}, \mathrm{b}$ - after annealing at $\mathrm{T}=1000^{\circ} \mathrm{C}$.

Mechanical properties

Typical technical and true strain curves of compressed samples are shown in Fig. 3.

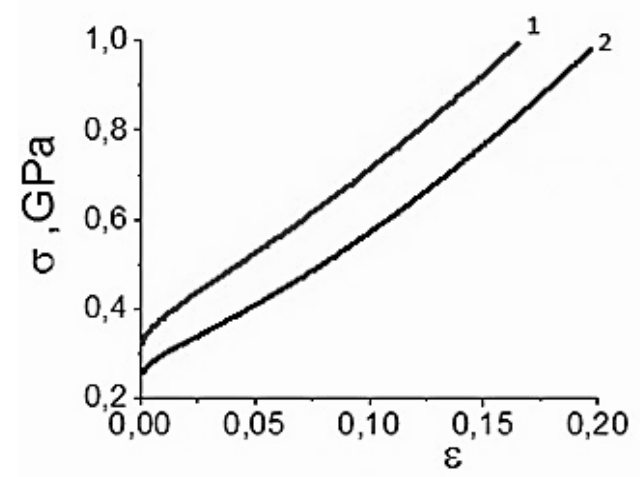

$\mathbf{a}$

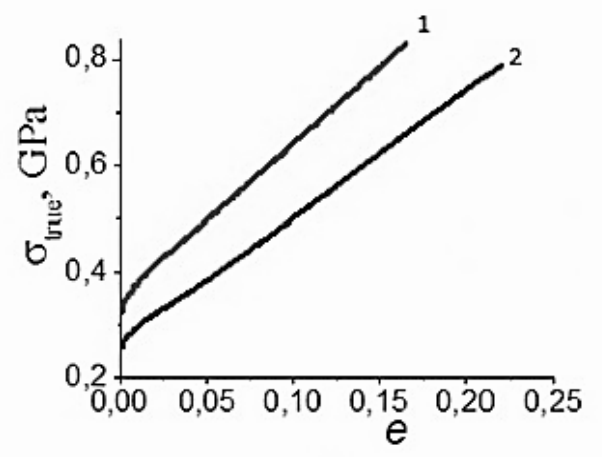

b

Fig. 3. Typical actual (a) and true (b) strain curves under uniaxial compression for CoCrFeMnNi (curve 1) and $\mathrm{Co}_{20} \mathrm{Cr}_{26} \mathrm{Fe}_{20} \mathrm{Mn}_{20} \mathrm{Ni}_{14}$ (curve 2) alloys

Recalculation of technical (actual) strain curves in true coordinates performed by standard formulas for compression deformation: 


$$
\sigma_{\text {true }}=\sigma(1-\varepsilon), e=-\ln (1-\varepsilon),
$$

where $\sigma_{\text {true }}$ - true stress, $e$ - true strain, $\sigma$-actual stress, $\varepsilon$-actual strain.

The hardness of both as-cast alloys was close and amounted to 1400-1500 MPa. Compression test also showed that the yield strength $\sigma_{0,2}$ was $262 \pm 2.5 \mathrm{MPa}$ for the equiatomic CoCrFeMnNi alloy and about $204 \pm 8 \mathrm{MPa}$ for the $\mathrm{Co}_{20} \mathrm{Cr}_{26} \mathrm{Fe}_{20} \mathrm{Mn}_{20} \mathrm{Ni}_{14}$ alloy. Both of these investigated alloys are plastic and do not break under compression rate more than $50 \%$.

Note that although the yield strength $\sigma_{0,2}$ is slightly lower for annealed $\mathrm{Co}_{20} \mathrm{Cr}_{26} \mathrm{Fe}_{20} \mathrm{Mn}_{20} \mathrm{Ni}_{14}$ alloy than that for the equiatomic alloy, after plastic deformation with $\varepsilon \geq 20 \%$ values $\sigma_{0,2}$ are almost identical for both alloys (Fig. $4 \mathrm{a}$ ), as well as hardness (Fig. 4b).
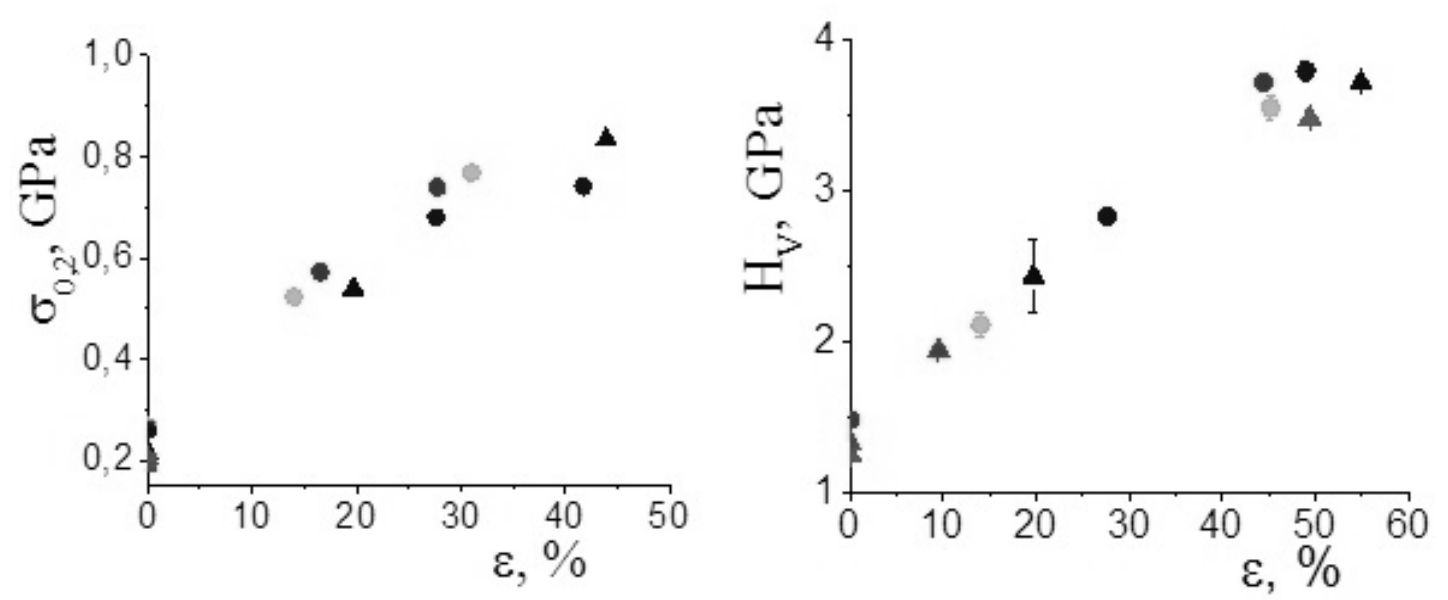

Fig. 4. Effect of the deformation degree on the yield strength (a) and hardness (b) of alloys. Circles - CoCrFeMnNi samples, triangles - $\mathrm{Co}_{20} \mathrm{Cr}_{26} \mathrm{Fe}_{20} \mathrm{Mn}_{20} \mathrm{Ni}_{14}$ samples

The behavior of the material under deformation is characterized by a hardening coefficient $\mathrm{d}_{\text {true }} / \mathrm{de}$ (Fig.5). As can be seen from Fig.5, dependences of the hardening coefficient on deformation are essentially different for the investigated alloys.

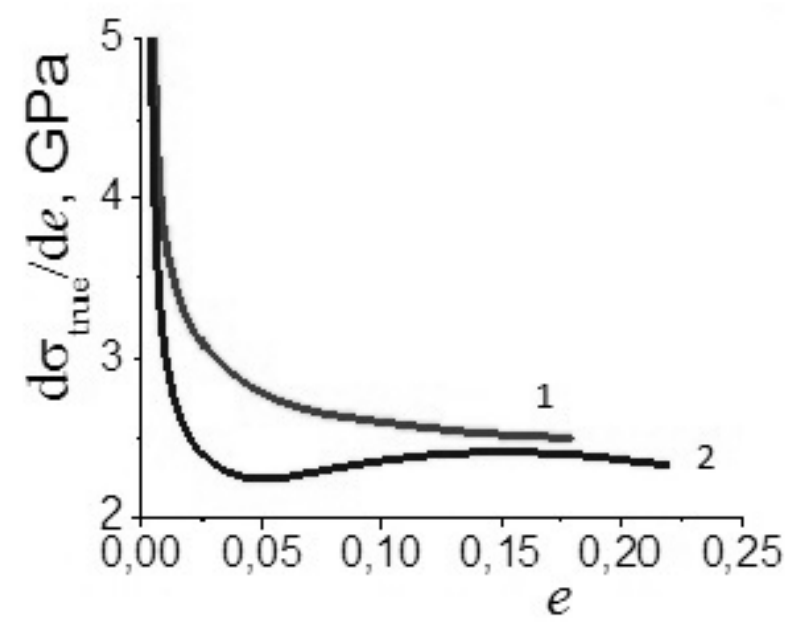

Fig. 5. Strain hardening coefficient dependency on true strain for CoCrFeMnNi (curve 1) and $\mathrm{Co}_{20} \mathrm{Cr}_{26} \mathrm{Fe}_{20} \mathrm{Mn}_{20} \mathrm{Ni}_{14}$ (curve 2) alloys

The behavior of $\mathrm{d} \sigma_{\text {true }} / \mathrm{de}$ for an equiatomic alloy is typical for FCC metals - at the initial stage the coefficient falls sharply and then it gradually decreases [6,8]. In the $\mathrm{Co}_{20} \mathrm{Cr}_{26} \mathrm{Fe}_{20} \mathrm{Mn}_{20} \mathrm{Ni}_{14}$ alloy three phases of the hardening coefficient change are observed: a sharp fall on the initial stage with a minimum at $\mathrm{e} \approx 0,05$, a growth of d $\sigma_{\text {true }} / \mathrm{de}$ up to deformations of $\mathrm{e} \approx 0,15-0,17$, and a further gradual decline. The greatest interest is the second phase, which can mean the activation of a new deformation mechanism. A similar behavior of the hardening coefficient was observed in [6] on the equiatomic CoCrFeMnNi alloy in the case of deformation at $77 \mathrm{~K}$, when a twinning mechanism was activated at a certain deformation stage. As it known, the low stacking-fault energy promotes twinning. So, it can be expected that a critical twinning stress is achieved at a certain degree of strain hardening in non-equiatomic $\mathrm{Co}_{20} \mathrm{Cr}_{26} \mathrm{Fe}_{20} \mathrm{Mn}_{20} \mathrm{Ni}_{14}$ alloy that has very low stacking-fault energy $\left(3,5 \mathrm{mJm}^{-2}\right.$ [7]), even in the case of room temperature a twinning occures along with dislocation gliding. 
Twin boundaries acts as an obstacles and delays the dislocations motion, which leads to the increasing of the hardening coefficient. But further research is needed to experimentally confirm this assumption.

\section{CONCLUSIONS}

1. Equiatomic CoCrFeMnNi and non-equiatomic $\mathrm{Co}_{20} \mathrm{Cr}_{26} \mathrm{Fe}_{20} \mathrm{Mn}_{20} \mathrm{Ni}_{14}$ high-entropy alloys are single-phase $\mathrm{FCC}$ solid solutions in as-cast state and after annealing at $1000^{\circ} \mathrm{C}$. Both alloys have a high plasticity and a significant ability to deformation hardening.

2. Although the mechanical properties at room temperature (yield strength and microhardness) at high compression strains are similar for both alloys, the behavior of the hardening coefficient in the range of true stress $\mathrm{e}=0,05-0,17$ is significantly defferent. This may indicate the implementation of various deformation mechanisms in these alloys at certain deformation stages, which caused by the difference in the stacking-fault energy.

\section{REFERENCES}

1. Murty B.S., Yeh J.W., Ranganathan S. High-entropy alloys. - Elsevier Science \& Technology (Elsevier inc), 2014. - 218 p.

2. Pogrebnjak A.D., Bagdasaryan A.A., Yakushchenko I.V., Beresnev V.M. The structure and properties of high-entropy alloys and nitride coatings based on them // Russian Chemical Reviews. - 2014. - Vol.83. - No.11. - P.1027-1061.

3. Cantor B., Chang I.T.H., Knight P., Vincent A.J.B. Microstructural development in equiatomic multicomponent alloys // Materials science and engineering. -2004.- Vol. A375-377. - P.213-218.

4. Salishchev G.A., Tikhonovsky M.A., Shaisultanov D.G., Stepanov N.D., Kuznetsov A.V., Kolodiy I.V., Tortika A.S., Senkov O.N. Effect of $\mathrm{Mn}$ and V on structure and mechanical properties of high-entropy alloys based on FeCrCoNi system // Journal of Alloys and Compounds. - 2014. - No.591. - P.11-21.

5. Stepanov N., Tikhonovsky M., Yurchenko N., Zyabkin D., Klimova M., Zherebtsov S., Salishchev G., Efimov A. Effect of cryo-deformation on structure and properties of CoCrFeNiMn high-entropy alloy // Intermetallics. - 2015. - Vol.59. - No. 4. P.8-17.

6. Laplanche G., Kostka A., Horst O.M., Eggeler G., George E.P. Microstructure evolution and critical stress for twinning in the CrMnFeCoNi high-entropy alloy // Acta materialia. - 2016. - Vol.118. - P.152-163.

7. Zaddach A.J., Niu C., Koch C.C., Irving D.L. Mechanical properties and stacking fault energies of NiFeCrCoMn high-entropy alloy // J. of Metals. - 2013. - Vol.65. - P. 1780-1789.

8. Tikhonovsky M.A., Tortika A.S., Kolodiy I.V., Stoev P.I., Rudycheva T.Y., Berezhnaya N.S., Tantsjura I.G. Microstructure and properties of high entropy alloys $\mathrm{CoCrFeMnNiV} \mathrm{V}_{0.25} \mathrm{C}_{0.175}$ and $\mathrm{CrFe}_{2} \mathrm{MnNiV}_{0.25} \mathrm{C}_{0.175}$ // Problems in atomic Science and Technology (PAST). Series "Physics of radiation defects and radiation materials science". - 2016. - Vol. 4(104). - P.37-41. 